\title{
AGRONEGÓCIO: A ATUAÇÃO DO ENGENHEIRO DE PRODUÇÃO NOS PROCESSOS DE CAMPO
}

\author{
Congresso Nacional Online de Empreendedorismo, 3ạ edição, de 06/12/2021 a 08/12/2021
} ISBN dos Anais: 978-65-81152-30-7

\begin{abstract}
SANTOS; Italo Coutinho dos ${ }^{1}$, OLIVEIRA; Vinicius Fernandes de ${ }^{2}$, MASSON; Fábio Junior
\end{abstract} ${ }^{3}$, LEAL; Luciano ${ }^{4}$, OLIVEIRA; Maria Ester de ${ }^{5}$

\section{RESUMO}

O agronegócio no Brasil é de grande importancia, o país oferece grandes condições para que essa área seja ampla envolvendo muitos fatores de produção como, por exemplo: a criação de gado, a venda e produção de produtos agrícolas,usinas de produção de álcool, a estocagem de grãos entre outros fatores. No Brasila evolução do agronegócio só tem aumentado nos últimos anos, as condições climáticas são muito adversas em várias regiões facilitando bastante a vida dosprodutores com seus cultivos e criações tanto no crescimento da safra como apreparação do solo tanto para o plantio como para a preparação do pasto. Assim,se tratando do agronegocio, tal aspecto se torna mais relevante, tendo em vista que, diferentemente de outros setores econômicos, não possui capacidade própria deformação de preço, este é determinado pelo mercado. O agronegócio sempre ocupou posição de destaque na economia e exige profissionais bem capacitados para a execução das mais diversas atividades para participar do processo produtivo e influenciar os resultados. Os objetivos do presente trabalho circundaram entre descrever a importância do agronegócio no Brasil, sobretudo nas cidades de menor porte; apresentar o papel do engenheiro de produção no agronegócio; realizar o levantamento bibliográfico para compreender a importância do agronegócio com o auxílio do engenheiro de produção; analisar as aplicações práticas do engenheiro de produção no agronegócio. Para que alcançasse o almejado, o trabalho foi dividido em quatro etapas, que consiste no levantamento de dados a partir de referencial bibliográfico, a eleição dos dados e informações relacionando o engenheiro de produção com o agronegócio; o caráter multidisciplinar da engenharia de produção; e a identificação das principiais áreas de atuação do engenheiro de produção voltado para o agronegócio. Pelo seu caráter multidisciplinar, a engenharia de produção se faz necessária em agência bancárias, pois este irá aumentar significativamente aretenção de lucros, tendo em vista que ele irá gerir melhor os projetos e métodos, iráfacilitar o processo de traçar o perfil do produtor, aplicando na prática os processosde pessoas que este viu nos bancos da faculdade, além de dispor dos recursos necessários para a produção e o produtor.

PALAVRAS-CHAVE: agronegócio, engenharia de produção, aperfeiçoamento 